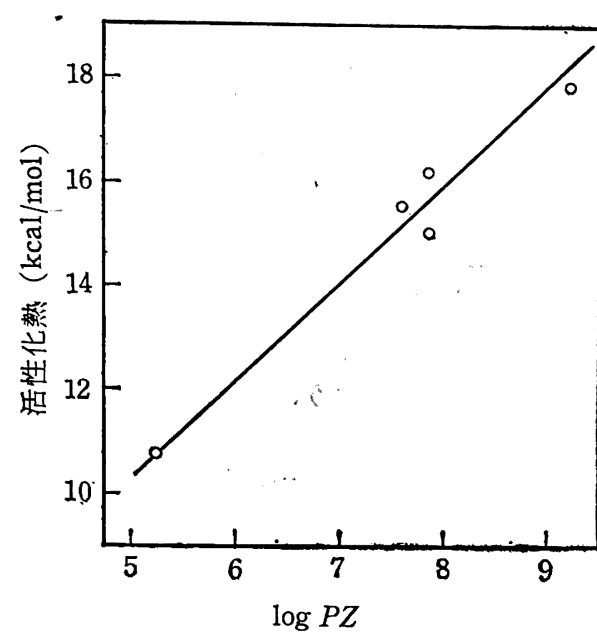

図 13 活性化熱と活性定数の関係

キサン, DMSO, THF のような非プロトン溶媒-水系では非プロ トン溶媒の増加にしたがってUアニオンの “Solvated Cage” は 分散されて小さくなり Cage に含まれる分極したF分子す減少す るために低い $[\mathrm{F}]_{\mathrm{c}}$ を与えるすのと考えられる。一方，水分子と の溶媒和が減少し, 分極した $\mathrm{F}$ 分子との反応も速かに行われるも のと思われる。

\section{6 尿素誘導体の反成速度}

$70 \%$ ジオキサンー水混合溶媒を用いて尿素誘導体 $0.1 \mathrm{~mol} / l$, $[\mathrm{NaOH}] 3.636 \times 10^{-4} \mathrm{~mol} / l,[\mathrm{~F}] 5.875 \times 10^{-2} \mathrm{~mol} / l$, 反応温度

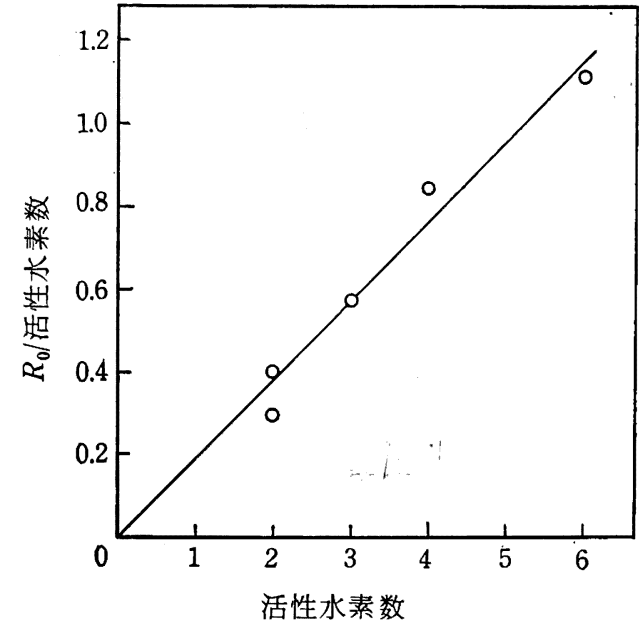

図 14 尿素誘導体の反応速度

$40 \pm 0.05^{\circ} \mathrm{C}$ で反応を行ない，それぞれの $R_{0}$ と活性水素数との 関係を図 14 に示した。この結果, 反応速度は次の順となり, 活 性水素数の多いほどメチロール化反応は速かに行われることがわ かる。

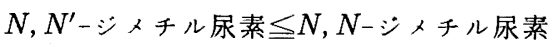

$$
\begin{aligned}
& <N-\rtimes チ ル \text { 尿素<尿素くメチレンジ尿素 }
\end{aligned}
$$

終りに，終始御討論をいただきました大阪市大工学部竹本喜一 助教授, 小林慎江博士に感謝致します。

\title{
ノボラック樹脂に対するジアゾ化アニリンのカップリングと, そのへキサメチレンテトラミンによる硬化†
}

(昭 和 39 年 3 月 14 日 受 理)

井本 稔* 中嶋直一**.田嶋自然**. 竹本喜一*

ノボラック樹脂に種々のモル比のジアゾ化アニリンをカップリングさせ，樹脂 $1 \mathrm{~mol}$ あたり 1 ～4.5のアゾ基をふく む着色生成体を得た。これらカップリング体をさらにへキサメチレンテトラミンにより種々の条件下で硬化させ，その際 の不溶化率をもとめた。硬化体は不溶性であり，粉末化によって浸色性を示さない高分子顔料とすることができる。

\section{1 緒言}

従来アゾ顔料の製造に拉いて，ジアゾ成分に対するカップリン グ成分として，高分子物質を用いるこころみはほとんどみられな い。著者らはホルムアルデヒド系樹脂研究の一環として, ノボラ ック樹脂が，ジアゾ化合物に対するカップリング成分として有効 であり, 低分子のフェノール類, ナフトール類などの場合と同様, きわめて容易にジアゾ化アニリンをカップリングして着色した樹 脂を与えることを見出した。ノボラック樹脂とジアゾ化アミン類 との反応で顔料をつくり得ることは最近, Paikachev らによって

$\dagger$ 本報を「ホルムアルデヒド系樹脂に関する研究 (第 80 報)」 とする．前報は斎藤，井本，工化 67, 1086 (1964).

* 大阪市立大学工学部: 大阪市北区南扇町.

** 富士色素株式会社：兵庫県川西市小花.
も報告されたが1)，著者らはノボラック樹脂に種々のモル比のジ アゾ化アニリンをカップリングさせ，その反応生成体の性質をし らべるとともに，さらにへキサメチレンテトラミンを用い，種々 の条件下で硬化反応を行なって，不溶化率をもとめた。得られた 硬化体を粉末化して耐溶媒性，かつ浸色性を示さない高分子顔料 を得ることがでさる。

\section{2 実験および結果}

$2 \cdot 1$ ノボラック樹脂に対するジアゾ化アニリンのカップリン グ

精製アニリン $4.65 \mathrm{~g}(0.05 \mathrm{~mol}) ， 30 \%$ 塩酸 $15.1 \mathrm{~g}$ 打よび水 $460 \mathrm{ml}$ の系を $0^{\circ} \mathrm{C}$ にたもち，かきまぜ下に亜硝酸ナトリウム

1) Y.S. Paikachev, S.S. Frolov, Khim. Prom. 1962, 242 ; Chem. Abst. 57, 6062 (1962). 
$3.45 \mathrm{~g}$ の $20 \mathrm{ml}$ 水溶液を徐々に添加して, ジアゾニウム塩を合 成した。これを，ノボラック樹脂 (5 核体，分子量 520$) 26.0 \mathrm{~g}$ $(0.05 \mathrm{~mol})$, 水酸化ナトリウム $5.0 \mathrm{~g}(0.12 \mathrm{~mol})$ 扤よび水 2600 $\mathrm{m} l$ よりなる $10^{\circ} \mathrm{C}$ の系の中にかきをぜながら約 15 分をかけて 添加すると, 黄褐色の生成物が沈殿した。反応終了後, 希塩酸を 滴下して $\mathrm{pH}$ を 7.0 とし，約 1 時間さらにかきまぜたのち，沈 殿体を口別し, 水洗ののち $60^{\circ} \mathrm{C}$ で乾燥して黄褐色の着色したカ ップリング体 $31.0 \mathrm{~g}$ (理論值 $31.2 \mathrm{~g}$ ) を得た。このものはつぎ のよ5に, 樹脂 1 分子中に平均 1 個のアゾ基を有する構造のもの と考えられる。たとえば,

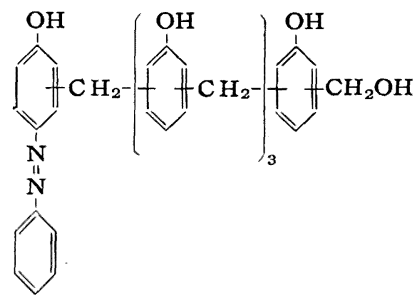

同様にしてカップリングの祭のジアゾニウム塩と, ノボラック 樹脂のモル比を $2 / 1,3 / 1,4 / 1$, 执よび $5 / 1$ として, 樹脂 1 分子 中に平均それぞれ理論量として $2 ， 3 ， 4$ 护よび 5 個のアゾ基を 有するものを合成した。生成カップリング体の性質は表 1 に示す ようである。

表 1 生成カップリング体の性質

\begin{tabular}{|c|c|c|c|c|c|}
\hline 番 号 No. & 1 & 2 & 3 & 4 & 5 \\
\hline 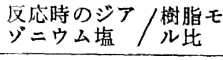 & $1 / 1$ & $2 / 1$ & $3 / 1$ & $4 / 1$ & $5 / 1$ \\
\hline 生成体の外纘 & $\begin{array}{l}\text { 黄裼色 } \\
\text { 枌末 }\end{array}$ & $\begin{array}{l}\text { 焱黄褐 } \\
\text { 色粉末 }\end{array}$ & $\begin{array}{l}\text { 暗黄色 } \\
\text { 粉末 }\end{array}$ & $\begin{array}{l}\text { 暗黄色 } \\
\text { 粉末本 }\end{array}$ & $\begin{array}{l}\text { 暗黄色 } \\
\text { 粉末 }\end{array}$ \\
\hline 点 $(\mathrm{C})$ & $65 \sim 73$ & $103 \sim 110$ & $106 \sim 113$ & $98 \sim 103$ & $102 \sim 108$ \\
\hline $\mathrm{N}$ 含量(実測) (\%) & 4. 25 & 7. 39 & 9.14 & 10.46 & 12.37 \\
\hline 同 上(計算) $(\%)$ & 4. 29 & 7.40 & 9.76 & 11.61 & 13. 10 \\
\hline $\begin{array}{l}\text { 樹脂 } 1 \mathrm{~mol} \text { あだ } \\
\text { のの゙基の数** }\end{array}$ & 1.0 & 2. 0 & 2.7 & 3.4 & 4.5 \\
\hline
\end{tabular}

表 1 からわかるよ5に，反応させるジアジニウム塩の量が多い 場合には，生成カップリング体のアゾ基含量は理論量より少なく なる傾向がみられた。

カップリング体は水のほか四塩化炭素, トルエンに不溶である が, ジオキサン，ジメチルスルホキシド，テトラヒドロフラン， アセトンには溶解する。また，エタノールには，アゾ基の量が少 ないほど，クロロホルム，ベンゼンにはそれが多いほど溶解性が みられるようになる。

\section{$2 \cdot 2$ ヘキサメチレンテトラミンによる硬化}

$2 \cdot 1$ の実験条件で得られた 5 種のカップリング体について，そ れぞれ 10 部にヘキサメチレンテトラミン 1 部を混合して $120^{\circ} \mathrm{C}$ ないし $170^{\circ} \mathrm{C} ， 2$ 時間までの範囲内で硬化を行なった。反応後, 内容物を粉砕したのち，水拉よびアセトンで 18２0 時間抽出し

表 2 カップリング体のへキサメチレンテトラミンに よる硬化：硬化条件と不溶性分生成率との関係

\begin{tabular}{cccccc} 
陚 & \multicolumn{2}{c}{$140 \mathrm{C}$} & \multicolumn{2}{c}{$170 \mathrm{C}$} \\
\cline { 5 - 6 } ノボラック餗脂 & $74.31 \%$ & $79.42 \%$ & $97.61 \%$ & $98.64 \%$ \\
No. 1 & 67.30 & 74.37 & $91.13^{\mathrm{a})}$ & 95.17 \\
No. 2 & 55.96 & 53.61 & 80.13 & 94.22 \\
No. 3 & 32.71 & 49.59 & 83.29 & 86.91 \\
No. 4 & 51.00 & 54.41 & 70.84 & 81.83 \\
No. 5 & 51.77 & 47.34 & 48.74 & 58.54 \\
a) 便化時問 $45 \mathrm{~min} \quad$ b) & 同 $105 \mathrm{~min}$ & &
\end{tabular}

て，未反応のヘキサメチレンテトラミンおよび可溶分を除去，完 全に乾燥して暗黄色の不溶性分を得た。

カップリング体 No. 1 および No. 3 について，それそれ各種

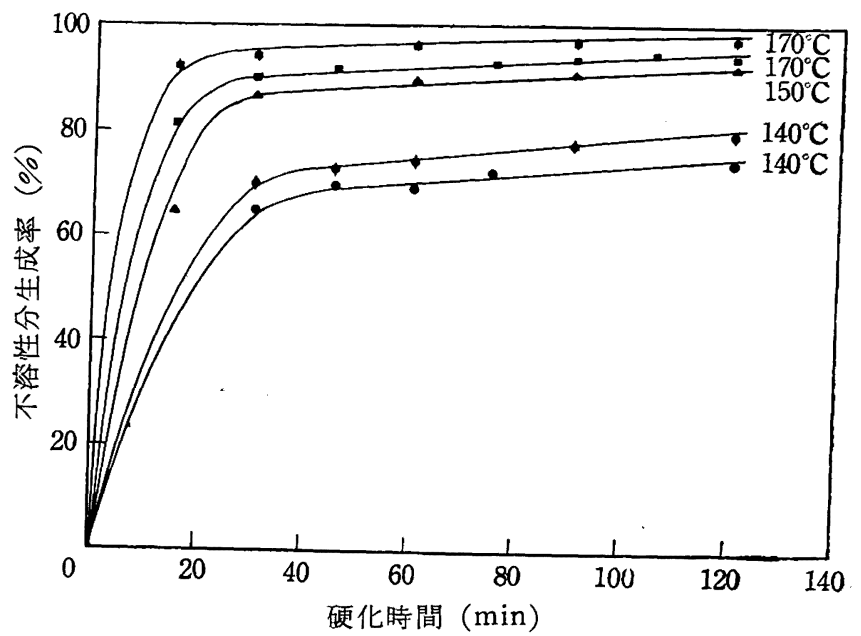

図 1 ノボラック樹脂およびカップリング体 (No. 1) のへキサメチレンテトラミンによる硬化：硬化 時間と不溶性分生成率との関倸

由：ノボラック樹脂

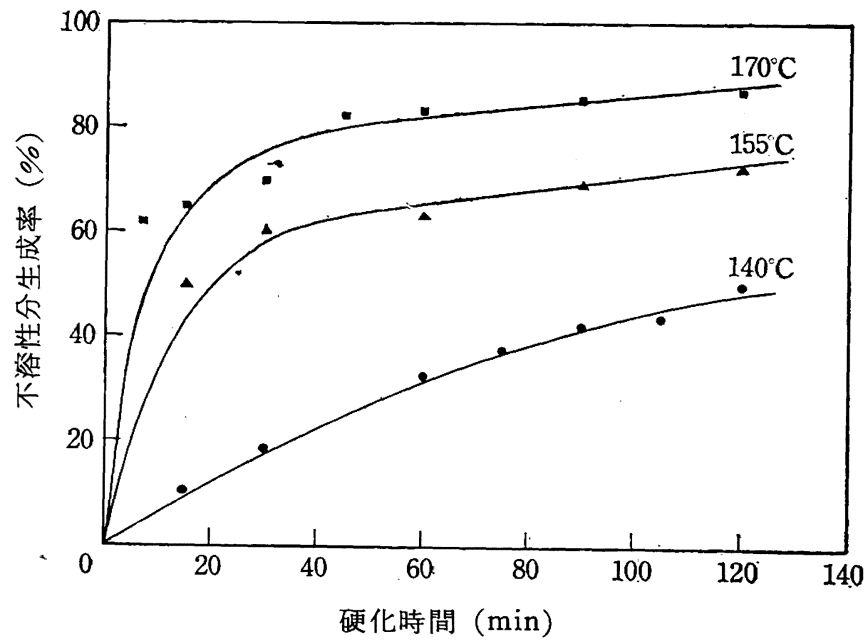

図 2 カップリング体（No. 3) のへキサメチレンテトラミ ンによる硬化：硬化時間と不溶性分生成率との関係

表 3 硬化体の展色に括ける色相の主波長, 純度および 明度（展色剂：ニトロセルロースラッカー）

\begin{tabular}{|c|c|c|c|c|c|}
\hline 試料 & $\begin{array}{c}\text { 硬化温度 } \\
{ }^{\left({ }^{2} \mathrm{C}\right)}\end{array}$ & $\begin{array}{c}\text { 硬化時間 } \\
(\mathrm{min})\end{array}$ & $\begin{array}{c}\text { 主波長 } \\
(\mathbf{m} \mu)\end{array}$ & $\begin{array}{l}\text { 純度 } \\
(\%)\end{array}$ & $\begin{array}{l}\text { 明度 } \\
(\%)\end{array}$ \\
\hline \multirow{4}{*}{ No. 1} & 140 & 60 & 584.5 & 86.9 & 16.2 \\
\hline & 140 & 120 & 582.1 & 92.1 & 16. 31 \\
\hline & 170 & 60 & 578.9 & 85.0 & 16.0 \\
\hline & 170 & 120 & 581.0 & 71.4 & 5.45 \\
\hline \multirow{4}{*}{ No. 2} & 140 & 60 & 592.0 & 81.4 & 8.55 \\
\hline & 140 & 120 & 592.0 & 75.0 & 13.51 \\
\hline & 170 & 60 & 589.8 & 67.7 & 6.1 \\
\hline & 170 & 120 & 588.3 & 66.2 & 5. 6 \\
\hline \multirow{4}{*}{ No. 3} & 140 & 60 & 591.5 & 79.7 & 7.75 \\
\hline & 140 & 120 & 591.0 & 80.9 & 7.68 \\
\hline & 170 & 60 & 594.9 & 64.4 & 6.3 \\
\hline & 170 & 120 & 591.6 & 67.6 & 5.19 \\
\hline \multirow{4}{*}{ No. 4} & 140 & 60 & 595.0 & 75.5 & 6.3 \\
\hline & 140 & 120 & 590.8 & 74.1 & 5.7 \\
\hline & 170 & 60 & 584.0 & 60.9 & 4. 09 \\
\hline & 170 & 120 & 585.0 & 54.2 & 3.8 \\
\hline \multirow{4}{*}{ No. 5} & 140 & 60 & 590.5 & 81.5 & 6.1 \\
\hline & 140 & 120 & 586.5 & 65.6 & 3.9 \\
\hline & 170 & 60 & 575.5 & 37.4 & 2. 99 \\
\hline & 170 & 120 & 579.5 & 55.0 & 3.3 \\
\hline
\end{tabular}


反応温度についての硬化時間と, 不溶性分生成率との関係を, 図 1 特よび図 2 亿示した。図1 亿はさらに，ジアジ化アニリンをカ ップリングしない，もとのノボラック樹脂そのものの同条件に拈 ける硬化の結果をるめわせて示した。また硬化時間が一定の場合 の, No. 1 5 の 5 種の不溶化率の比較を表 2 亿示した。これら の結果から、へキサメチレンテトラミンによるカップリング体の 硬化は反応温度の高いほど速いこと，またカップリング体につい てはアゾ基の含量の小さなものほど同条件下では硬化は大である
が，ノボラック樹脂とのるのの硬化はさらに大であることがわか る。

以上のようにして得られた不溶性の硬化体を微粉末状とし，二 トロセルロースラッカーで展色試験を行なった。色相の主波長, 純度打よび明度を表 3 に示した。硬化体は水，アルコール，アセ トン, ベンゼンなどに浸色性を示さないため，粉末状にすること によりラッカー, メラミンなどの塗料や，プラスチックス用の顔 料とすることができる。

\section{$-ノ-ト-$}

三塩化アンチモンとアルコールおよびアミンとの反応によるアンチモントリアルコキシドの合成

(昭 和 38 年 10 月 17 日 受 理)

木島一郎・高橋 伸 江*

一般に，金属アルコキシドは金属ハロゲン化物とアルコールと の反応によって得られるが，多くの場合脱塩酸剤の存在が必要て ある。すでに著者らは, 脱塩酸剤としてアミンを用いて, チタニ ウム ${ }^{1,2)}$ や， ジルコニウム3) の塩化物とアルコールとの反応によ り，相当する金属のテトラアルコキシドや，モノクロルトリアル コキシドが得られることを報告した。本報告では，金属ハロゲン 化物として三塩化アンチモンを用いて，アルコール捛よびアミン との反応を検討した。

アンチモントリアルコキシドについては, 三塩化アンチモンと アルコール扰よび無水硫酸銅を用いる方法4), アンチモントリエ トキシドと他のアルコールとの交換反応による方法 ${ }^{5,6)}$, 拉よび, 三塩化アンチモンとアルコール拈よびナトリウム7)や，アンモニ $ア^{8 \sim 13)}$ との反応による方法などが報告されているが，三塩化アン チモンとアルコールとの反応による場合に, 脱塩酸剤としてアミ

* 東京理科大学工学部：東京都新宿区神楽坂.

1) 好野, 木島, 杉山, 高井, 工化 64, 1010 (1961).

2) 好野, 木島, 杉山, 金沢, 工化 64，1182 (1961)；65, 556 (1962).

3）木島, 分島, 好野, 工化 65，559 (1962).

4) Mac Key, J. Chem. Soc. 95, 606 (1909).

5) B. A. Arbuzov, V.S. Vinogradova, Izvest. Akad. Nauk S.S.S.R. Otdel. Khim Nauk 1951, 551-553; Chem. Abst. 46, 7995.

6) O.D. Dubrovina, Ucheye Zapiski. Kazan. Gosundarst. Univ im V. I. U1'yanov-Lenina 116, No. $2, \quad 3 \sim 70$ (1956) ; Chem. Abst. 51, 6534.

7) H. Meerwein, T.Bersin, Ann. 476, 113 150 (1929).

8) M. G. Voronkov, Ya.I. Skorik, Izvest. Akad. Nauk S.S.S.R. Otdel Khim Nauk 1958, 503 504; Chem. Abst. 52, 17093.

9) J.H. Haslam, U.S.P. 2, 839, 554, June 17 (1958).

10) J.H.Haslam, Brit.P. 787, 180, Dec. 4 (1957).

11) J.H. Haslam, U.S.P. 2, 684, 972, July 27 (1954).

12) L. J. Carbonnean, D. C. Downing, Can. J. Chem. 34, 184 (1956).

13) C. Russias, A. Deluzarche, A. Maillard, Compt. rend. 254, 698 (1962).
ンを用いた報告はない。

著者らの研究によると, 三塩化アンチモンとイソプロピルアル コールとの反応に，アミンとして，ジェチルアミン，トリェチル アミン，ピペリジン，モノーn-ブチルアミンおよびジーn-ブチル アミンを用いた時には，アミン滴下の際，かなりの発熱が認めら れ，アンチモントリイソプロポキシド扰よび用いたアミンの塩酸 塩が得られた。しかし，ピリジン，アニリン， 芳香族アミンとの反応では, 同様に発熱するが, トリイソプロポ キシドを単離することはできず，ピリジンや，o-トルイジンでは 次に示寸分析值から，付加物と考えられる白色結晶が得られた。

\begin{tabular}{|c|c|c|c|}
\hline \multirow{2}{*}{$\begin{array}{l}\text { 三壏化アンチモン・物 } \\
\text { アミン物 }\end{array}$} & \multirow{2}{*}{ [分解点] } & \multicolumn{2}{|c|}{ 分 析 值 [計算値] } \\
\hline & & $\mathrm{Sb} \%$ & $\mathrm{Cl} \%$ \\
\hline & {$\left[185^{\circ} \mathrm{C}\right]$} & $32.75[31.26]$ & $28.92[27.53]$ \\
\hline $\mathrm{SbCl}_{3} \cdot 3 o-\mathrm{CH}_{3} \mathrm{C}_{6} \mathrm{H}_{5} \mathrm{NH}_{2}$ & {$\left[67^{\circ} \mathrm{C}\right]$} & $21.84[22.15]$ & 19. $27[19.36]$ \\
\hline
\end{tabular}

アニリンを用いた場合は，かなりの塩素を含有する白色結晶が 得られるが，その組成については，明らかにしえなかった。従っ て, 三塩化アンチモンとアルコールとからアンチモントリアルコ キシドを合成する際の脱塩酸剂として，これら芳香族アミンのよ 5に，塩基性の弱いアミンは有効でない。一方，脂肪族アミンで も, トリーnーブチルアミンでは，脱塩酸剂としての作用は認めら れなかった。

次に, 種々のアルコール(メチルー, エチルー, n-ブチル-, secブチル-, tert-ブチルアルコール) についても同様にアミン類を 用いて，三塩化アンチモンとの反応を検討したが，メチルアルコ 一ルを除いては, 著しい違いは認められなかった。特に, tert-ブ チルアルコールでは, tert-ブトキシ基による塩素原子の置換が困 難になるものと予想したが，他のアルコールとほとんど違いが認 められず，いずれのアルコールも塩基性の強いアミン類について は, アンチモントリイソプロポキシドとほとんど同様な収率で, アンチモントリアルコキシドが得られた。これらはいずれす無色 透明の液体で，表 1 に示すような沸点をもっている。メチルアル コールを用いた場合には，同様な方法でトリメトキシドを単離す ることができなかったので, アンチモントリイソプロポキシドと 過剩のメチルアルコールを用いて，アルコール交換反応にてアン 